\title{
Long-term in vitro exposure to high glucose increases proinsulin-like-molecules release by isolated human islets
}

\author{
F Bertuzzi ${ }^{1}$, K Saccomanno ${ }^{5}$, C Socci ${ }^{1}$, A M Davalli ${ }^{2}$, \\ M V Taglietti ${ }^{3}$, C Berra ${ }^{3}$, E Dalcin ${ }^{4}$, L D Monti ${ }^{3}$, G Pozza $^{3}$ and \\ A E Pontiroli ${ }^{2}$
}

${ }^{1}$ Istituto Scientifico San Raffaele, Chirurgia $2{ }^{a},{ }^{2}$ Unità Malattie Metaboliche, ${ }^{3}$ Medicina Interna, ${ }^{4}$ Anatomia Patologica, Università degli Studi di Milano, Milan, Italy and ${ }^{5}$ Istituto di Scienze Endocrine, Ospedale Maggiore, Milan, Italy

(Requests for offprints should be addressed to F Bertuzzi, Istituto Scientifico San Raffaele, Via Olgettina 60, I-20132 Milan, Italy)

\begin{abstract}
The aim of this study was to determine the effect of long-term in vitro exposure to high glucose on the release and content of proinsulin and insulin in human islets. After $48 \mathrm{~h}$ culture in CMRL medium at $5.5 \mathrm{mM}$ (control islets) and $16.7 \mathrm{mM}$ glucose (experimental islets), islets were perifused and acutely stimulated with $16.7 \mathrm{mM}$ glucose, followed by $3 \cdot 3 \mathrm{mM}$ glucose. Compared with control islets, experimental islets showed a higher basal release of true insulin and proinsulin-like-molecules (PLM), with no increase of true insulin and PLM release in response to $16.7 \mathrm{mM}$ glucose, and a paradoxical true insulin release in response to $3.3 \mathrm{mM}$ glucose; the $\mathrm{PLM} /$ total insulin ratio
\end{abstract}

increased significantly after $16.7 \mathrm{mM}$ glucose. Moreover these islets showed a decreased true insulin content and an increased PLM/total insulin ratio. Quantitative ultrastructural analysis of granules, supported by double gold immunostaining with monoclonal antibodies against proinsulin and insulin, showed an increased proinsulin to insulin ratio in $\beta$-cells from experimental islets. These data support in vitro what was recently shown in vivo, and further confirm that culture in high glucose is a useful tool to mimic the effect of in vivo chronic hyperglycemia on human $\beta$-cell function.

Journal of Endocrinology (1998) 158, 205-211

\section{Introduction}

Proinsulin-like-molecules (PLM) consist of several molecules on the pathway of production of insulin from proinsulin (C-peptide and intact and partially processed proinsulin) with a low insulin-like biological activity (Temple et al. 1989). PLM have been found elevated in type II diabetic patients (NIDDM) (Polonsky \& Rubenstein 1989, Temple et al. 1989), in newly diagnosed type I diabetic patients (IDDM) (Snorgaard et al. 1990), in healthy siblings (Lindgren et al. 1993) or twins of IDDM patients (Heaton et al. 1988), as well as in elderly subjects (Shimizu et al. 1996). Different hypotheses have been proposed to understand the etiology of high PLM levels: (1) a primary dysfunction in insulin secretion (Porte \& Kahn 1989); (2) a consequence of chronic hyperglycemia; and (3) a decreased proinsulin clearance (Polonsky \& Rubenstein 1989, Porte 1991, Rhodes \& Alarcon 1994).

Primary islet dysfunction as the cause of high PLM is supported by the finding of hyperproinsulinemia without hyperglycemia in identical relatives of IDDM patients (Heaton et al. 1988), or by clinical situations of increased metabolic demand without hyperproinsulinemia such as in patients with pharmacologically induced insulin resistance (Kahn et al. 1989a), in partial pancreatectomized dogs
(Ward et al. 1988) or in obese Pima Indians (Kahn et al. 1989b).

High serum levels of PLM could be related to an increased secretory demand placed on $\beta$-cells, as it has recently been shown to occur after hemipancreatectomy (Seaquist et al. 1996), in the presence of glucose intolerance (Shiraishi et al. 1991), in cystic fibrosis (Hartling et al. 1988), or after prolonged intravenous glucose administration (Davis et al. 1993). Cross-sectional data in NIDDM have shown that increased PLM occurs after the onset of hyperglycemia (Birkeland et al. 1994). Finally, many but not all studies have found partial to full normalization of the PLM in patients with hypoglycemic therapies (Yoshioka et al. 1989). This hypothesis was also confirmed in animal models of NIDDM in which hyperproinsulinemia has been described as the result of the premature release of proinsulin before it could be fully processed (Alarcon et al. 1995, Gadot et al. 1995). An immunocytochemical study showed an impaired processing of proinsulin due to a chronic secretory state (Bendayan et al. 1995).

We have previously shown that in vitro culture of isolated human islets in the presence of high glucose is a suitable model to mimic the effects of in vivo chronic hyperglycemia (Davalli et al. 1991, 1992). The aim of the 
Table 1 True insulin and PLM release and content of islets cultured in 5.5 and $16.7 \mathrm{mM}$ glucose. True insulin and PLM release are expressed as pg/islet per min during basal release and as pg/islet per $20 \mathrm{~min}$ ( $A \cup C$ and $\triangle$-AUC) after glucose stimulation or inhibiiton $(n=12$; four replicates from three pancreata). True insulin and PLM content are expressed as $n g /$ islet $(n=33 ; 11$ replicates from three pancreata). Means \pm S.E.

\begin{tabular}{|c|c|c|}
\hline & $5 \cdot 5 \mathrm{mM}$ glucose & $16.7 \mathrm{mM}$ glucose \\
\hline \multicolumn{3}{|l|}{ Islet secretion $(n=12)$} \\
\hline \multicolumn{3}{|l|}{ True insulin } \\
\hline Basal & $4 \cdot 6 \pm 0.5$ & $9 \cdot 0 \pm 1 \cdot 0^{\star *}$ \\
\hline After glucose stimulus (AUC) & $438 \cdot 3 \pm 91 \cdot 3$ & $160 \cdot 5 \pm 16 \cdot 9^{*}$ \\
\hline After glucose stimulus ( $\Delta$-AUC) & $346 \cdot 6 \pm 91 \cdot 5$ & $-18 \cdot 9 \pm 19 \cdot 0^{* *}$ \\
\hline After glucose inhibition (AUC) & $192 \cdot 4 \pm 25 \cdot 7$ & $264 \cdot 4 \pm 26 \cdot 3$ \\
\hline After glucose inhibition ( $\Delta$-AUC) & $-168 \cdot 9 \pm 22 \cdot 8$ & $64 \cdot 9 \pm 40 \cdot 0^{* *}$ \\
\hline \multicolumn{3}{|l|}{ PLM } \\
\hline Basal & $2 \cdot 9 \pm 0 \cdot 3$ & $4 \cdot 4 \pm 0 \cdot 6^{*}$ \\
\hline After glucose stimulus (AUC) & $112 \cdot 8 \pm 40 \cdot 2$ & $73 \cdot 6 \pm 15 \cdot 2$ \\
\hline After glucose stimulus ( $\Delta$-AUC) & $54 \cdot 4 \pm 41 \cdot 4$ & $-15 \cdot 3 \pm 16 \cdot 7$ \\
\hline After glucose inhibition (AUC) & $64 \cdot 6 \pm 13 \cdot 6$ & $121 \cdot 6 \pm 30 \cdot 9$ \\
\hline After glucose inhibition ( $\Delta$-AUC) & $-26 \cdot 4 \pm 31 \cdot 3$ & $60 \cdot 3 \pm 21 \cdot 2^{*}$ \\
\hline \multicolumn{3}{|l|}{ PLM/total insulin } \\
\hline Basal & $0.39 \pm 0.03$ & $0 \cdot 33 \pm 0 \cdot 03$ \\
\hline After glucose stimulus & $0 \cdot 18 \pm 0 \cdot 03$ & $0 \cdot 29 \pm 0 \cdot 04^{*}$ \\
\hline After glucose inhibition & $0 \cdot 23 \pm 0 \cdot 04$ & $0 \cdot 27 \pm 0 \cdot 04$ \\
\hline \multicolumn{3}{|l|}{ Islet content $(n=33)$} \\
\hline True insulin & $12 \cdot 82 \pm 1 \cdot 39$ & $5 \cdot 53 \pm 0 \cdot 61^{* *}$ \\
\hline PLM & $4.02 \pm 0.59$ & $2 \cdot 90 \pm 0 \cdot 37$ \\
\hline PLM/total insulin & $0 \cdot 22 \pm 0 \cdot 02$ & $0 \cdot 34 \pm 0 \cdot 02^{* *}$ \\
\hline
\end{tabular}

present study was to verify, by the same model, the effects of high glucose on proinsulin content and PLM release of human islets.

\section{Materials and Methods}

\section{Islets isolation}

Islets were isolated from human pancreata from multiorgan donors using a modification of the automated method and purified by centrifugation on a Euroficoll discontinuous gradient (Sigma Chemical Co., St Louis, MO, USA) (Socci et al. 1991). The mean age of the donors was $35 \pm 10$ years. Ethical Committee approval had been obtained.

\section{In vitro culture}

After a $12 \mathrm{~h}$ overnight culture at $37^{\circ} \mathrm{C}$ in CMRL 1066 $(10 \%$ fetal calf serum, $2 \mathrm{mM} \mathrm{L-glutamine,} 100 \mathrm{U} / \mathrm{ml}$ penicillin, and $100 \mu \mathrm{g} / \mathrm{ml}$ streptomycin sulfate) in $95 \% \mathrm{O}_{2}: 5 \% \mathrm{CO}_{2}$, groups of 100 islets $(150-200 \mu \mathrm{m}$ in diameter) were hand picked and transferred to CMRL 1066 with $5.5 \mathrm{mM}$ glucose (control islets), or $16.7 \mathrm{mM}$ glucose (experimental islets).

\section{Perifusions}

After $48 \mathrm{~h}$ culture in low or high glucose concentration, two experiments were performed with each batch of islets. Aliquots of 100 hand picked islets from three pancreata were put overnight in tubes containing $1 \mathrm{ml}$ acid-alcohol for insulin and PLM extraction. The following day, tubes were centrifuged for $10 \mathrm{~min}$ at 2000 r.p.m. at $4{ }^{\circ} \mathrm{C}$, and diluted samples of the supernatant were stored at $-20{ }^{\circ} \mathrm{C}$ for assay of the insulin and PLM content. Insulin and PLM release were measured by perifusion experiments as follows. After a $40 \mathrm{~min}$ equilibration period at $3.3 \mathrm{mM}$ glucose, islets were acutely stimulated with $16.7 \mathrm{mM}$ glucose for $20 \mathrm{~min}$, followed by $3.3 \mathrm{mM}$ glucose for $20 \mathrm{~min}$.

\section{Assays}

Total insulin (true insulin plus PLM) was assayed by RIA, using commercial kits (RIA Kits, Incstar, Stillwater, MN, USA). In our laboratory this RIA has the following characteristics: intra-assay coefficient of variation (CV) $3 \%$, interassay $5 \%$, recovery of added doses $98-100 \%$, minimum sensitivity $12 \mathrm{pmol} / \mathrm{l}$.

True insulin was assayed by Micro-particle Enzyme Immunoassay (MEIA insulin, IMX System, Abbott 
Laboratories, Abbot Park, IL, USA). In our laboratory, MEIA has the following characteristics: intra-assay CV $3 \%$, interassay $5 \%$, recovery of added doses $98-100 \%$, minimum sensitivity $6.0 \mathrm{pmol} / 1$.

PLM were obtained by subtracting values of MEIA from insulin RIA values (Monti et al. 1995). This method has the following characteristics: intra-assay $\mathrm{CV}<1.6 \%$ and $2.5 \%$ at low and at medium-high values, recovery of added doses $87-99 \cdot 7 \%$, minimum sensitivity $4 \cdot 0 \mathrm{pmol} / 1$. Our procedure to evaluate PLM was compared with a commercial kit for proinsulin assay by ELISA (Total Proinsulin, Dako, Milan, Italy). Even if a 20\% overestimation was found with our procedure, a highly significant correlation was demonstrated between the two assays $(r=0 \cdot 99 ; P<0 \cdot 001)$.

\section{Electron microscopy and quantitative evaluation}

Islets of Langerhans from six pancreata were processed for electron microscopy as previously described (Saccomanno et al. 1993). Briefly, the islets were fixed for $2 \mathrm{~h}$ in $2.5 \%$ glutaraldehyde in $0.1 \mathrm{M}$ cacodylate buffer. They were then post-fixed in $1 \% \mathrm{OsO}_{4}$ in cacodylate buffer at $4{ }^{\circ} \mathrm{C}$ for $1 \mathrm{~h}$, dehydrated in graded ethanol up to propylene oxide and finally embedded in an Epon-Araldite mixture. Well preserved areas rich in granules were identified by light microscopy of semi-thin sections $(0.5 \mu \mathrm{m})$. Subsequently, serial ultra-thin sections $(80 \mathrm{~nm})$ were mounted on 200-mesh copper grids, stained with uranyl acetate and lead citrate, and finally examined with a Zeiss CEM 902 electron microscope.

Each preparation was thoroughly scanned and well preserved areas composed of $\beta$-cells were photographed and analyzed at a final magnification of $\times 15750$. Insulin and proinsulin granules were identified by morphologic characteristics supported by immunolocalization results. Insulin granules were characterized by a paracrystalline electron dense core and a well delimited membrane, proinsulin granules by ovoid or rounded slightly electron dense core delimited by a membrane. The number of insulin and proinsulin granules was counted over a median area of $1126 \mu \mathrm{m}^{2}$ (ranging from 421 to $2257 \mu \mathrm{m}^{2}$ ) for each preparation and expressed per $500 \mu \mathrm{m}^{2}$. Granules with morphology of equivocal interpretation were considered mixed.

\section{Immunolocalization}

Immunoelectron microscopy was carried out using the double gold labeling for the detection of both insulin and proinsulin on three out of six pancreatic islet preparations fixed in paraformaldehyde $4 \%$ and LR-White embedded, according to the procedure previously described, with some modifications. Briefly, islet sections were incubated with normal goat serum in order to avoid non-specific labeling and then incubated with monoclonal anti-human
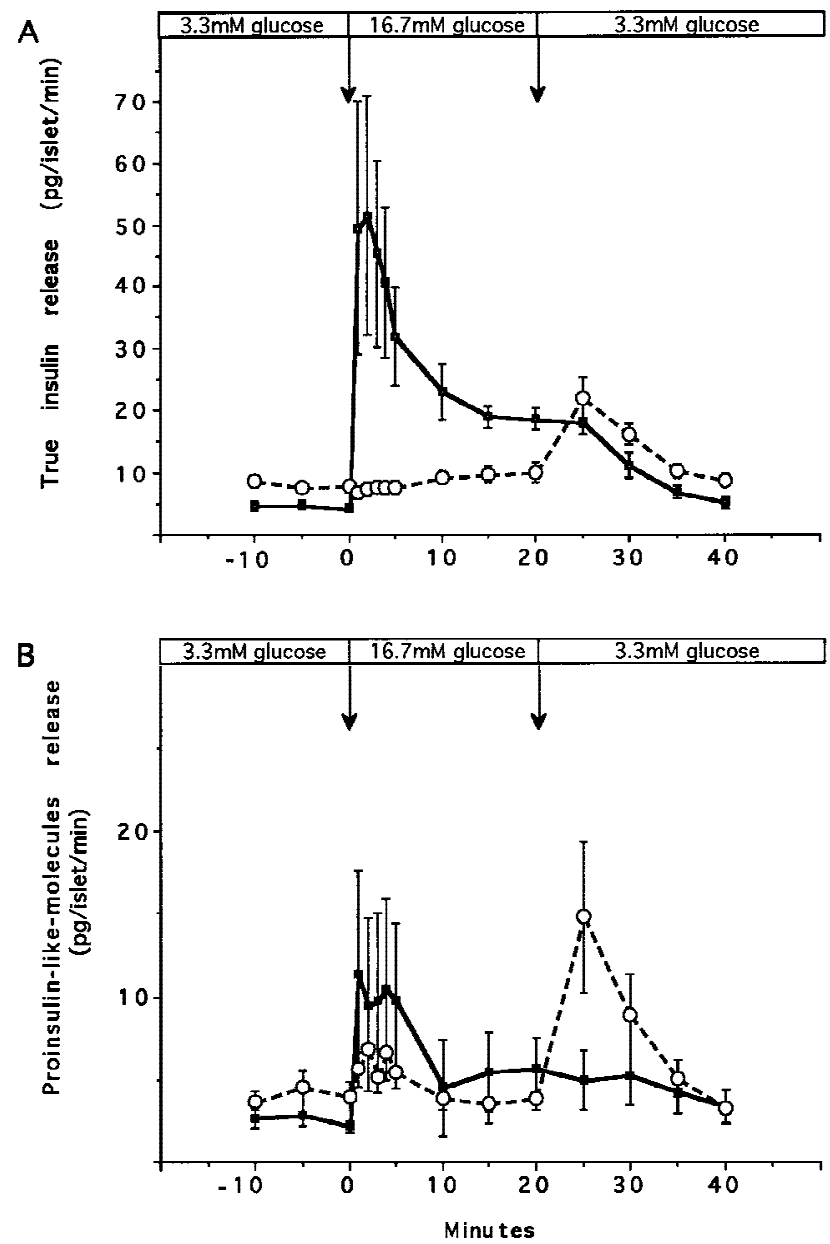

Figure 1 (A) True-insulin release of islets cultured in $5.5 \mathrm{mM}$ glucose ( $\mathbf{\square})$ and in $16.7 \mathrm{mM}$ glucose $(\bigcirc)$. After a $40 \mathrm{~min}$ equilibration period in $3.3 \mathrm{mM}$ glucose, islets were acutely stimulated for $20 \mathrm{~min}$ with $16.7 \mathrm{mM}$ glucose, followed by $3.3 \mathrm{mM}$ glucose for $20 \mathrm{~min}$. Means \pm S.E. $(n=12$, four replicates from three pancreata). (B) PLM release in islets cultured in $5.5 \mathrm{mM}$ glucose $(\boldsymbol{\square})$ and in $16.7 \mathrm{mM}$ glucose $(\bigcirc)$. Means \pm S.E. $(n=12$, four replicates from three pancreata).

proinsulin sera (Novo Nordisk Biolabs, Bagsvaerd, Denmark) diluted $1: 10$ in PBS+1\% BSA. After $1 \mathrm{~h}$ at $37^{\circ} \mathrm{C}$ islets were labeled with $5 \mathrm{~nm}$ colloidal gold particles coated with goat anti-mouse IgG (YLEM s.rl., Avezzano, Italy). After several washes, the sections were incubated with monoclonal anti-human insulin sera (Immunotech, Marseille, France) diluted 1:10 in PBS+1\% BSA and labeled with $10 \mathrm{~nm}$ colloidal gold particles coated with goat anti-mouse $\operatorname{IgG}$. At the end the sections were rinsed in PBS several times and in twice-distilled water, fixed in $2 \cdot 5 \%$ glutaraldehyde and stained with uranyl acetate. No cross reactivity has been described for anti-human proinsulin sera with human insulin and human C-peptide. The specificity of the immunostaining was tested by 


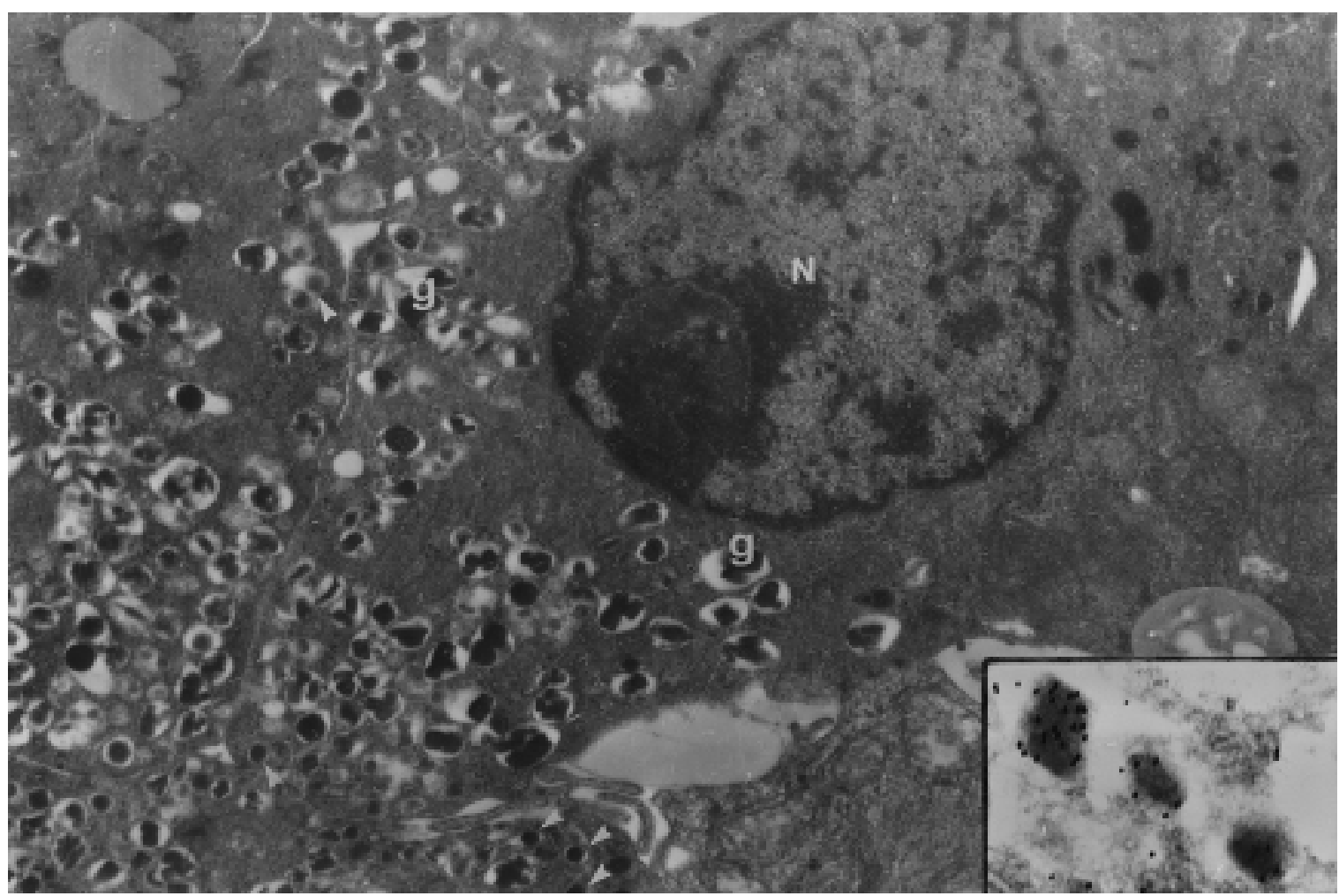

Figure 2 Electron microscopy of a glutaraldehyde-fixed and Epon-embedded $\beta$-cell after a $48 \mathrm{~h}$ incubation in $5.5 \mathrm{mM}$ glucose. The cell appears full of dense paracrystalline core granules (g), which are positive for insulin as shown by immunogold labeling (inset); only a small number of round granules without a crystalline core are recognizable as proinsulin granules (arrows). $\mathrm{N}$ : nucleus.

substituting normal mouse serum for anti-insulin and proinsulin antisera, and by absorption of antisera with their respective purified antigens $(10 \mathrm{nmol}$ antigen $/ \mathrm{ml}$ diluted antiserum). Granules with a double immunostaining were considered mixed.

\section{Calculations and statistical analysis}

Data are always expressed as means \pm s.E. Integrated insulin release during perifusions was calculated by the linear trapezoidal method (area under the curve, AUC, and the variation of area under the curve, $\Delta$-AUC) and was expressed as pg/islet per $20 \mathrm{~min}$; an insulin secretion index was also calculated as the ratio between peak and basal insulin values. Comparisons were performed by Student's $t$-test for unpaired data. $P$ values $<0.05$ were considered statistically significant.

\section{Results}

True insulin release

Islets cultured in $16.7 \mathrm{mM}$ glucose released more true insulin under basal conditions $(3.3 \mathrm{mM}$ glucose $)$ than control islets (Table 1) and showed a decreased insulin response to an acute glucose stimulus, both in terms of the AUC and $\triangle$-AUC (Table 1), and in secretion index $(1 \cdot 1 \pm 0.1$ vs $11 \cdot 2 \pm 3.5 ; n=12 ; P<0 \cdot 05)$; further, these islets showed a paradoxical insulin release in response to a low glucose concentration (Table 1, Fig. 1A).

\section{PLM release}

Islets cultured in high glucose released more PLM during basal conditions and showed a paradoxical PLM release after low glucose (Table 1, Fig. 1B), with no difference compared with control islets during the acute glucose stimulus (Table 1).

The PLM/total insulin ratio was higher in islets cultured in high glucose than in control islets, after high glucose challenge, with no differences during basal conditions and after low glucose (Table 1).

\section{True insulin and PLM content}

Islets cultured in high glucose showed a decreased true insulin content; PLM content was unchanged as an 


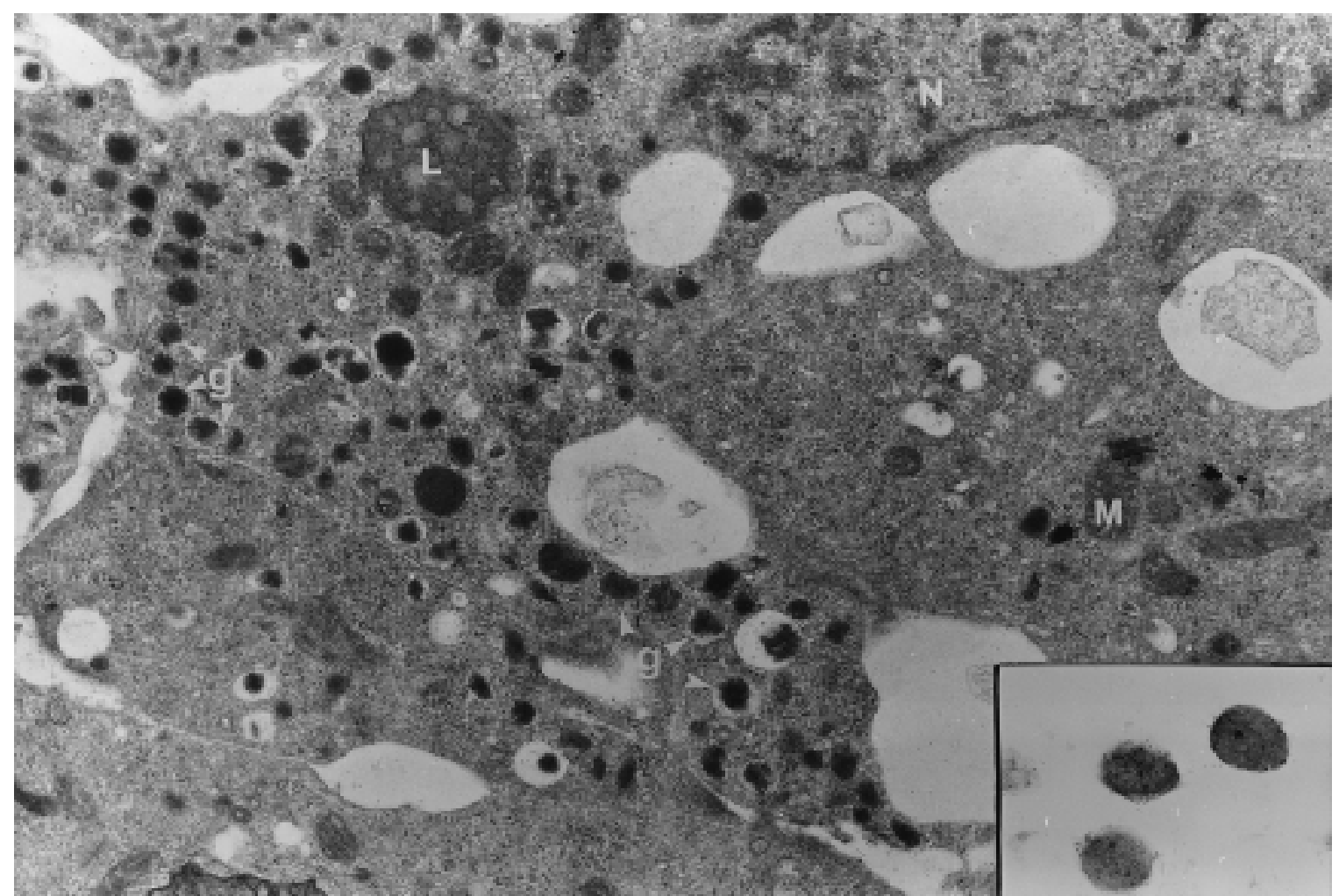

Figure 3 Electron microscopy of a glutaraldehyde-fixed and Epon-embedded $\beta$-cell after a $48 \mathrm{~h}$ incubation in $16.7 \mathrm{mM}$ glucose. Note the prevalence of round or ovoid granules without crystalline cores (g) positive for proinsulin as shown by immunogold labeling (inset); only few granules show a more dense paracrystalline core (insulin-rich). N: nucleus; M: mitochondria.

absolute value, and increased as a PLM/total insulin ratio (Table 1).

\section{Electron microscopy and immunolocalization}

By electron microscopy, $\beta$-cells cultured in control medium were characterized by a large amount of secretory granules with a dense crystalline core, surrounded by a clear halo (Fig. 2); $\beta$-cells cultured in high glucose contained in particular round or ovoid secretory granules, without a crystalline halo (Fig. 3). Golgi apparatus and rough endoplasmic reticulum were well developed in both cases. A prevalence of mitochondria, lysosomes and vacuolization of the cytoplasm was observed in islets cultured in high glucose.

Immunolocalization of insulin and proinsulin by double immunogold technique localized insulin in mature granules, as exemplified in Fig. 2 for control islets, and proinsulin in immature granules from islets cultured in high glucose (Fig. 3). Absorption of anti-proinsulin sera with an excess of purified proinsulin produced a drastic decrease in labeling intensity; nevertheless absorption with insulin did not result in any variation in the proinsulin labeling pattern.
The morphometric analysis per $500 \mu \mathrm{m}^{2}$ revealed, in islets cultured in high glucose, a decrease in insulincontaining granules as absolute number, although not statistically significant $(P=0 \cdot 08)$, and as percentage of total granule number, while proinsulin granules, unchanged as absolute number, increased in percentage of total granule number (Table 2).

\section{Discussion}

We have studied the effects of long-term exposure to high glucose on human islets content and release of insulin and PLM. We confirmed that human islets cultured for $48 \mathrm{~h}$ in $16.7 \mathrm{mM}$ glucose lose the capability to release insulin after an acute glucose stimulus, show a paradoxical response to a glucose inhibition, and secrete significantly more insulin than control islets under basal conditions (Davalli et al. 1991, Ling \& Pipeleers 1996). In this study we show that islets cultured in high glucose secrete more PLM at $3.3 \mathrm{mM}$ glucose than control islets, and show a relative increase in the PLM/total insulin ratio after glucose stimulation. Hormone extraction showed that $\beta$-cells exposed to high glucose contain less true insulin than 
Table 2 Number of insulin, proinsulin and mixed granules per $500 \mu \mathrm{m}^{2}$ in $\beta$-cells of islets cultured in 5.5 and $16.7 \mathrm{mM}$ glucose. Percentage of total number of granules is in parentheses. Means \pm S.E., $n=6$ (mean from six pancreata)

\section{$5 \cdot 5 \mathrm{mM}$ glucose}

\section{Granule type}

Insulin

Proinsulin

Mixed

Total

**P<0.001 vs $5.5 \mathrm{mM}$ glucose islets.

control islets. This is not surprising, in fact $\beta$-cell degranulation is expected to occur after chronic stimulation and has been found in several experimental situations of increased metabolic demand (Curry 1986, Leahy 1993). Immunocytochemical staining for proinsulin and insulin granules demonstrated an increased proinsulin to insulin ratio in $\beta$-cells kept in high glucose, similar to that already reported in animal models of NIDDM (Bendayan et al. 1995). The paradoxical release of insulin to a glucose inhibition as well as high insulin release in basal conditions could be a consequence of a glucose hypersensitivity due to an impaired translocation of glucokinase (Noma et al. 1996), an up-regulated hexokinase (Hosokawa et al. 1995), or a subcellular shift of the enzyme to mitochondria (Rabuazzo et al. 1997).

The increase of PLM release and relative proinsulin content suggests that chronic glucose stimulation unbalances the rates of biosynthesis, intracellular degradation and release of insulin from $\beta$-cells, or simply that insulin is released before its maturation is complete. However, human islets transplanted into diabetic nude mice and maintained in hyperglycemia for 4-6 weeks, showed an impairment in glucose-induced insulin release accompanied by normal proinsulin biosynthesis (Eizirik et al. 1997); in rat islets, insulin biosynthesis and proinsulin conversion enzyme (PC2/PC3) activity have been shown to be unaffected by a long-term in vitro exposure to high glucose; the decreased PC2-PC3 content appears to be due to an increased release and not to a change in biosynthesis (Alarcon et al. 1995). A variation in neither proinsulin conversion nor intra-islet degradation was observed (Gadot et al. 1995).

In NIDDM patients an increased proinsulin/insulin ratio has been observed under basal conditions, as well as in response to an acute glucose stimulus (Ward et al. 1987, Saad et al. 1990, Davis et al. 1993, Leahy 1993). During an oral glucose tolerance test, the ratio between serum proinsulin and total insulin is $42 \%$ in diabetic patients compared with 16\% in control patients (Leahy et al. 1992). These data are similar to those observed by us in the experimental islets after an acute glucose stimulation. In contrast, data on the release under basal condition are not in agreement with data in vivo; it should be pointed out, however, that basal insulin and proinsulin secretion are largely influenced in vivo by hormone clearance, glycemia, insulin resistance, body composition, and nervous and hormonal stimuli (Saad et al. 1990, Capito et al. 1992).

Moreover, the isolation procedure itself could be an islet stress situation and could impair the insulin secretion process, increasing proinsulin release (Pai et al. 1993).

In conclusion, this study demonstrates that human $\beta$-cells respond to a chronic glucose stimulation by increasing the relative proinsulin to insulin content and by releasing more PLM than control $\beta$-cells; this is similar to what happens in vivo in animal models of NIDDM and in humans (Seaquist et al. 1996). This confirms that culture in high glucose is a useful tool to mimic the effect of in vivo chronic hyperglycemia on human $\beta$-cell function.

\section{Acknowledgements}

This work was partially supported by the Italian Ministry of Health, the National Research Council (CNR, grant \#90.00034.PF70), Telethon (grant \#C.11; \#E.443), and Regione Lombardia (grant \#879).

\section{References}

Alarcon C, Leahy JL, Schuppin GT \& Rhodes CJ 1995 Increased secretory demand rather than a defect in the proinsulin conversion mechanism causes hyperproinsulinemia in a glucose-infusion rat model of non-insulin-dependent diabetes mellitus. Journal of Clinical Investigation 95 1032-1039.

Bendayan M, Malide D, Ziv E, Levy E, Ben-Sasson R, Kalman R, Bar-On H, Chretien M \& Seidah N 1995 Immunocytochemical investigation of insulin secretion by pancreatic $\beta$-cells in control and diabetic Psammomys obesus. Journal of Histochemistry and Cytochemistry 43 771-784.

Birkeland KI, Torjesen PA \& Eriksson J 1994 Hyperproinsulinemia of type II diabetes is not present before the development of hyperglycemia. Diabetes Care 17 1307-1310.

Capito K, Hansen SE, Hedeskov CJ, Islin H \& Thams P 1992 Fat-induced changes in mouse pancreatic islet insulin secretion, insulin biosynthesis and glucose metabolism. Acta Diabetologica $\mathbf{2 8}$ 193-198.

Curry DL 1986 Insulin content and insulinogenesis by the perfused rat pancreas: effects of long term glucose stimulation. Endocrinology 118 $170-175$.

Davalli AM, Ricordi C, Socci C, Braghi S, Bertuzzi F, Fattor B, Di Carlo V, Pontiroli AE \& Pozza G 1991 Abnormal sensitivity to glucose of human islets cultured in a high glucose medium: partial reversibility after an additional culture in a normal glucose medium. Journal of Clinical Endocrinology and Metabolism 72 202-208.

Davalli AM, Pontiroli AE, Socci C, Bertuzzi F, Fattor B, Braghi S, Di Carlo V \& Pozza G 1992 Human islets chronically exposed in vitro to different stimuli become unresponsive to the same stimuli given acutely: evidence supporting specific desensitization rather than $\beta$-cell exhaustion. Journal of Clinical Endocrinology and Metabolism 74 790-794.

Davis SN, Piatti PM, Monti L, Brown MD, Branch W, Hales CN \& Alberti KGMM 1993 Proinsulin and insulin concentrations following intravenous glucose challenges in normal, obese, and non-insulin-dependent diabetic subjects. Metabolism 42 30-35. 
Eizirik DL, Jansson L, Flodstrom M, Hellerstrom C \& Andersson A 1997 Mechanisms of defective glucose-induced insulin release in human pancreatic islets transplanted to diabetic nude mice. Journal of Clinical Endocrinology and Metabolism 82 2660-2663.

Gadot M, Ariav Y, Cerasi E, Kaiser N \& Gross DJ 1995

Hyperproinsulinemia in the diabetic Psammomys obesus is a result of increased secretory demand on the $\beta$-cell. Endocrinology 136 $4218-4223$.

Hartling SG, Garne S, Binder C, Heilmann C, Petersen W, Petersen KE \& Koch C 1988 Proinsulin, insulin, and C-peptide in cystic fibrosis after an oral glucose tolerance test. Diabetes Research and Clinical Practice 7 165-169.

Heaton DA, Millward BA, Gray IP, Tun Y, Hales CN, Pyke DA \& Leslie RDG 1988 Increased proinsulin levels as an early indicator of $\beta$-cell dysfunction in non-diabetic twins of type 1 (insulindependent) diabetic patients. Diabetologia 31 182-184.

Hosokawa H, Hosokawa YA \& Leahy JL 1995 Upregulated hexokinase activity in isolated islets from diabetic $90 \%$ pancreatectomized rats. Diabetes 44 1328-1333.

Kahn SE, Beard JC, Schwartz MW, Ward WK, Ding HL, Bergman RN, Taborsky GC \& Porte D 1989a Increased $\beta$-cell secretory capacity as mechanism for islet adaption to nicotinic acid-induced insulin resistance. Diabetes 38 562-568.

Kahn SE, Saad MF, Nelson RG, Pettit DJ \& Porte D Jr 19896 Disproportionately elevated proinsulin levels are a feature of NIDDM in Pima Indians. Clinical Research and Regulatory Affairs 37 $131 \mathrm{~A}$.

Leahy JL 1993 Increased proinsulin/insulin ratio in pancreas extracts of hyperglycemic rats. Diabetes 42 22-27.

Leahy JL, Bonner-Weir S \& Weir GC 1992 B-cell dysfunction by chronic hyperglycemia: current ideas on mechanism of glucoseinduced insulin secretion. Diabetes Care 15 442-454.

Lindgren FA, Hartling SG, Persson BE, Roder ME, Snellman K, Binder C \& Dahlquist G 1993 Proinsulin levels in newborn siblings of type 1 (insulin-dependent) diabetic children and their mothers. Diabetologia 36 560-563.

Ling Z \& Pipeleers DG 1996 Prolonged exposure of human beta cells to elevated glucose levels results in sustained cellular activation leading to a loss of glucose regulation. Journal of Clinical Investigation 98 2805-2812.

Monti LD, Sandoli EP, Phan VC, Piatti PM, Costa S, Secchi A \& Pozza G 1995 A sensitive and reliable method for assaying true human insulin without interaction with human proinsulin-like molecules. Acta Diabetologica 32 57-63.

Noma Y, Bonner-Weir S, Latimer JB, Davalli AM \& Weir GC 1996 Translocation of glucokinase in pancreatic beta-cells during acute and chronic hyperglycemia. Endocrinology 137 1485-1491.

Pai GM, Slavin BG, Tung P, Volk BW, Johnson DG, Anderson DG \& Levin SR 1993 Morphological basis of loss of regulated insulin secretion by isolated rat pancreatic islets. Anatomical Record 237 498-505.

Polonsky KS \& Rubenstein AH 1989 The kinetics and metabolism of insulin, proinsulin, and C-peptide. In Endocrinology, pp 1263-1289. Ed. LJ De Groot. Philadelphia: Saunders.

Porte D $1991 \beta$-cells in type II diabetes mellitus. Diabetes 40 166-180.
Porte D \& Kahn SE 1989 Hyperproinsulinemia and amyloid in NIDDM. Diabetes 38 1333-1336.

Rabuazzo AM, Patane G, Anello M, Piro S, Vigneri R \& Purrello F 1997 Hexokinase shift to mitochondria is associated with an increased sensitivity to glucose in rat pancreatic islets. Diabetes $\mathbf{4 6}$ $1148-1152$.

Rhodes CJ \& Alarcon C 1994 What $\beta$-cell defect could lead to hyperproinsulinemia in NIDDM. Diabetes 43 511-517.

Saad MF, Kahn SE, Nelson RG, Pettitt DJ, Knowler WC, Schwartz MW, Kowalyk S, Bennet PH \& Porte D 1990 Disproportionately elevated proinsulin in Pima Indians with non insulin-dependent diabetes mellitus. Journal of Clinical Endocrinology and Metabolism 70 $1247-1253$.

Saccomanno K, Taccagni G, Bosi E, Preti P, Dozio N \& Cantaboni A 1993 Immunoelectron microscopy: a new method for detection of insulin antibodies. Journal of Histochemistry and Cytochemistry 41 1233-1239.

Seaquist ER, Kahn SE, Clark PM, Hales CN, Porte D \& Robertson RP 1996 Hyperproinsulinemia is associated with increased $\beta$ cell demand after hemipancreatectomy in humans. Journal of Clinical Investigation 97 455-460.

Shimizu M, Kawazu S, Tomono T, Ohno T, Utsugi T, Kato N, Ishii C, Ito Y \& Murata K 1996 Age-related alteration of pancreatic $\beta$-cell function. Diabetes Care 19 8-11.

Shiraishi I, Iwamoto Y, Kuzuya T, Matsuda A \& Kumakura S 1991 Hyperinsulinaemia in obesity is not accompanied by an increase in serum proinsulin/insulin ratio in groups of human subjects with and without glucose intolerance. Diabetologia 34 737-741.

Snorgaard O, Hartling SG \& Binder C 1990 Proinsulin and C-peptide at onset and during 12 months cyclosporin treatment of type 1 (insulin-dependent) diabetes mellitus. Diabetologia 33 36-42.

Socci C, Falqui L, Davalli AM, Ricordi C, Braghi S, Bertuzzi F, Maffi P, Secchi A, Gavazzi F, Freschi M, Magistretti P, Socci C, Vignali A, Di Carlo V \& Pozza G 1991 Fresh human islet transplantation to replace pancreatic endocrine function in type I diabetic patients (a report of six cases). Acta Diabetologica 28 151-157.

Temple RC, Carrington CA, Luzio SD, Owens DR, Schneider AE, Sobey WJ \& Hales CN 1989 Insulin deficiency in non-insulindependent diabetes. Lancet i 293-295.

Ward WK, LaCava EC, Paquette TL, Beard JC, Wallum BJ \& Porte D 1987 Disproportionate elevation of immunoreactive proinsulin in type 2 (non-insulin-dependent) diabetes mellitus and in experimental insulin resistance. Diabetologia 30 698-702.

Ward WK, Wallum BJ, Beard JC, Taborsky GJ Jr \& Porte D Jr 1988 Reduction of glycemic potentiation: sensitive indicator of $\beta$-cell loss in partially pancreatectomized dogs. Diabetes 37 723-729.

Yoshioka N, Kuzuya T, Matsuda A \& Iwamoto Y 1989 Effects of dietary treatment on serum insulin and proinsulin response in newly diagnosed NIDDM. Diabetes 38 262-266.

Received 12 December 1997

Accepted 19 March 1998 